\title{
Extracellular polymeric substances and structural stability of aerobic granule
}

\author{
Sunil S. Adav ${ }^{a}$, Duu-Jong Lee, ${ }^{a, *}$ Joo-Hwa Tay ${ }^{b}$ \\ ${ }^{a}$ Department of Chemical Engineering, National Taiwan University, Taipei 10617, Taiwan \\ ${ }^{\mathrm{b}}$ Institute of Environmental Science and Engineering, Nanyang Technological University, Singapore
}

\section{A R T I C L E I N F O}

Article history:

Received 28 April 2007

Received in revised form

3 October 2007

Accepted 10 October 2007

Available online 15 October 2007

Keywords:

EPS

Stability

Hydrolysis

$\beta$-polysaccharides

\begin{abstract}
A B S T R A C T
The contributions of individual components in extracellular polymeric substances (EPSs) on structural stability of phenol-fed, aerobic granules were examined. The roles of proteins, $\alpha$ - and $\beta$-polysaccharides, and lipids were studied via their selective hydrolysis using enzymes, and the structural changes of granule were probed using in situ fluorescent staining and confocal laser scanning microscopy. Selective enzymatic hydrolysis of proteins, lipids, and $\alpha$-polysaccharides had a minimal effect upon the three-dimensional structural integrity of the granules. Conversely, selective hydrolysis of $\beta$-polysaccharides fragmented the granules. The $\beta$-polysaccharides were expected to form the backbone of a network-like outer layer with embedded proteins, lipids, $\alpha$-polysaccharides, and cells to support the mechanical stability of granules.
\end{abstract}

(c) 2007 Elsevier Ltd. All rights reserved.

\section{Introduction}

The aerobic granule process has been extensively investigated (Morgenroth et al., 1997; Beun et al., 1999; Peng et al., 1999; Tsuneda et al., 2003; Liu and Tay, 2004; de Kreuk et al., 2005; Chiu et al., 2006). Aerobic granules yield a high biomass concentration, settle fast under idle conditions (Liu and Tay, 2004), and have a capacity to degrade high-strength wastewater (Moy et al., 2002), or wastewater with high levels of toxicity (Jiang et al., 2002, 2004; Tay et al., 2004, 2005; Adav et al., 2007a, b).

Extracellular polymeric substances (EPSs) and cells form bioaggregates, such as biofilms and sludge flocs (Nielsen and Jahn, 1999). Microbial EPSs are biopolymers consisting of polysaccharides (Costerton et al., 1981), proteins, nucleic acids (Frolund et al., 1996; Nielsen et al., 1996), and lipids (Neu, 1996; Takeda et al., 1998). Failed microbial aggregation due to metabolic blocking of EPS synthesis has been described (Cammarota and Sant'Anna, 1998; Yang et al., 2004; Wu et al., 2006; Hwang et al., 2006). Quarmby and Forster (1995) identified a weak structure of anaerobic granules due to EPS deficiency.

Aerobic granule stability determines the feasibility of longterm aerobic granule processes (Liu et al., 2004a,b). Wang et al. (2005) and McSwain et al. (2005) demonstrated that some EPSs contribute primarily to the aerobic granule stability. Specifically, Wang et al. (2005) determined that non-soluble $\beta$-polysaccharide forms the outer shell of aerobic granules, providing granule strength. Conversely, McSwain et al. (2005) and Zhang et al. (2007) argued that a non-cellular protein core in aerobic granules provides stability. Thus, controversy exists regarding the roles of different components of EPSs in the structural stability of aerobic granules.

Chen et al. (2007a, b) was the first to describe the distributions of EPSs (proteins, $\alpha$ - and $\beta$-polysaccharides, and lipids) and cells (total and dead) in aerobic granules using a novel six-fold staining scheme and confocal laser scanning microscopy (CLSM). This work selectively hydrolyzed lipids, proteins, and $\alpha$ - and $\beta$-polysaccharides in phenol-degrading granules using specific enzymes. The staining scheme

\footnotetext{
*Corresponding author. Tel.: +8862 23625632; fax: +886223623040.

E-mail addresses: djlee@ntu.edu.tw, djlee@ccms.ntu.edu.tw (D.-J. Lee).
} 0043-1354/\$ - see front matter ๔ 2007 Elsevier Ltd. All rights reserved. doi:10.1016/j.watres.2007.10.013 
developed by Chen et al. (2007a) was employed to demonstrate qualitatively the distributions of the four components of EPSs in hydrolyzed granules.

\section{Materials and methods}

\subsection{Granules cultivation}

Aerobic granules were cultivated in a sequencing batch reactor (SBR), $5 \mathrm{~cm}$ in diameter and with a working height of $120 \mathrm{~cm}$. The SBR was inoculated with activated sludge from a municipal wastewater treatment plant in Taipei, Taiwan. A synthetic wastewater with phenol as the sole carbon source was used in this work. The composition of the synthetic wastewater is as follows: $1000 \mathrm{mgl}^{-1}$ phenol; $1000 \mathrm{mgl}^{-1}\left(\mathrm{NH}_{4}\right)_{2} \mathrm{SO}_{4} ; 200 \mathrm{mgl}^{-1} \quad \mathrm{MgCl}_{2} ; 100 \mathrm{mgl}^{-1} \mathrm{NaCl}$; $20 \mathrm{mgl}^{-1} \mathrm{FeCl}_{3} ; 10 \mathrm{mgl}^{-1} \mathrm{CaCl}_{2}$; phosphate buffer (1350 $\mathrm{mgl}^{-1}$ $\mathrm{KH}_{2} \mathrm{PO}_{4}, 1650 \mathrm{mgl}^{-1} \mathrm{~K}_{2} \mathrm{HPO}_{4}$ ); $\mathrm{pH}$ 6.8; and micronutrients $\left(\mathrm{gl}^{-1}\right): \mathrm{H}_{3} \mathrm{BO}_{3}, 0.05 ; \mathrm{ZnCl}_{2}, 0.05 ; \mathrm{CuCl}_{2}, 0.03 ; \mathrm{MnSO}_{4} \cdot \mathrm{H}_{2} \mathrm{O}\left(\mathrm{NH}_{4}\right)_{6}$, $0.05 ; \mathrm{Mo}_{7} \mathrm{O}_{24} \cdot 4 \mathrm{H}_{2} \mathrm{O}, 0.05 ; \mathrm{AlCl}_{3}, 0.05 ; \mathrm{CoCl}_{2} \cdot 6 \mathrm{H}_{2} \mathrm{O}, 0.05$; and $\mathrm{NiCl}, 0.05$ (Moy et al., 2002). The reactor was operated in 6-h cycles (5 min filling, $320 \mathrm{~min}$ aeration, $30 \mathrm{~min}$ settling, $5 \mathrm{~min}$ withdrawal). The effluent was withdrawn from an outlet located $50 \mathrm{~cm}$ above the reactor bottom. Air bubbles were supplied by diffusers located at the reactor bottom.

\subsection{Enzymes and granule treatment}

Proteinase $\mathrm{K}$, an endolytic protease that cleaves peptide bonds at the carboxylic sides of aliphatic, aromatic, or hydrophobic amino acids was utilized for protein hydrolysis tests. Lipase was used to enzymatically break down lipids into di- and mono-glycerides, glycerol and free fatty acids. $\alpha$-Amylase was used to break down $(\alpha 1 \rightarrow 4)$ glycosidic bonds between polymeric glucose units. $\beta$-Amylase was utilized to break down the $\beta$-linkages in polysaccharides. Preliminary tests with enzymes of different concentrations and reaction times revealed minimum diffusional limitation for enzyme transport through the granules.

The cultivated granules were separated equally into five groups. The granules in groups I-IV were hydrolyzed by proteinase $\mathrm{K}\left(2350 \mathrm{U}^{-1}\right.$ in phosphate-buffered saline (PBS), $\mathrm{pH}$ 8.0), lipase (3.15 $\mathrm{Ul}^{-1}$ in PBS, pH 8.0), $\alpha$-amylase (205 $\mathrm{Ul}^{-1}$ in PBS, $\mathrm{pH}$ 6.9), and $\beta$-amylase $\left(5.13 \mathrm{U}_{\mu} \mathrm{l}^{-1}, \mathrm{pH}\right.$ 5.0), respectively. The test tubes containing the granules and added enzymes were shaken in a rotary shaker at $150 \mathrm{rpm}$ for $60 \mathrm{~min}$ at $37^{\circ} \mathrm{C}$. The hydrolyzed granules were then washed with PBS buffer. Group V granules were directly shaken in a rotary shaker at $150 \mathrm{rpm}$ for $60 \mathrm{~min}$ at $37^{\circ} \mathrm{C}$ as a control.

\subsection{Granule staining}

The control and hydrolyzed granules were stained using the following scheme proposed by Chen et al. (2007a). Briefly, fluorescein isothiocyanate (FITC) was utilized to stain aminereactive compounds such as proteins and amino sugars. Fluorescently labelled lectin concanavalin A (Con A) conjugated with tetramethyl rhodamine was applied to bind the $\alpha$-mannopyranosyl and $\alpha$-glucopyranosyl sugar residues. The
SYTO 63 stain, a cell-permeative nucleic acid stain, differentiates extracellular polymeric substances from cells. Calcofluor white (Sigma, St. Louis, USA) was utilized to stain the $\beta$-D-glucopyranose polysaccharides. Nile red was utilized to stain lipids and SYTO blue was used to stain dead cells. All probes were purchased from Molecular Probes, Eugene, USA. The staining sequence and wavelengths of CLSM imaging are available in Chen et al. (2007a).

\subsection{EPS extraction}

The EPSs in original and hydrolyzed granules were extracted using formamide and sodium hydroxide. The carbohydrate content in the EPSs was then measured using the Anthrone method (Gaudy, 1962) with glucose as the standard. The protein content in the EPSs was determined using the Lowry method with bovine serum albumin as the standard (Lowry et al., 1951; Frolund et al., 1996).

The lipids, polar and neutral lipids, were extracted from granules by adding methanol/chloroform (1:2 v/v). The supernatant from the extract after 5 -min centrifugation was treated with sodium chloride $(0.9 \% \mathrm{w} / \mathrm{v})$. The mixture was then mixed and centrifuged, and the organic phase (oily phase) was recovered as a lipid extract. The total lipid content was acquired by evaporating the organic solvent and drying in an oven at $45^{\circ} \mathrm{C}$ for $15 \mathrm{~min}$.

\subsection{Analytical methods}

Volatile suspended solids of aerobic granules were measured using Standard Methods (APHA, 1998). Washed granules were fixed with $2.5 \%$ glutaraldehyde for $2 \mathrm{~h}$, suspended in osmium after water washing, and dehydrated via successive passages through $30 \%, 50 \%, 75 \%, 85 \%, 90 \%, 95 \%$, and $100 \%$ ethanol, and subjected to critical drying for scanning electron microscopic (SEM) analysis.

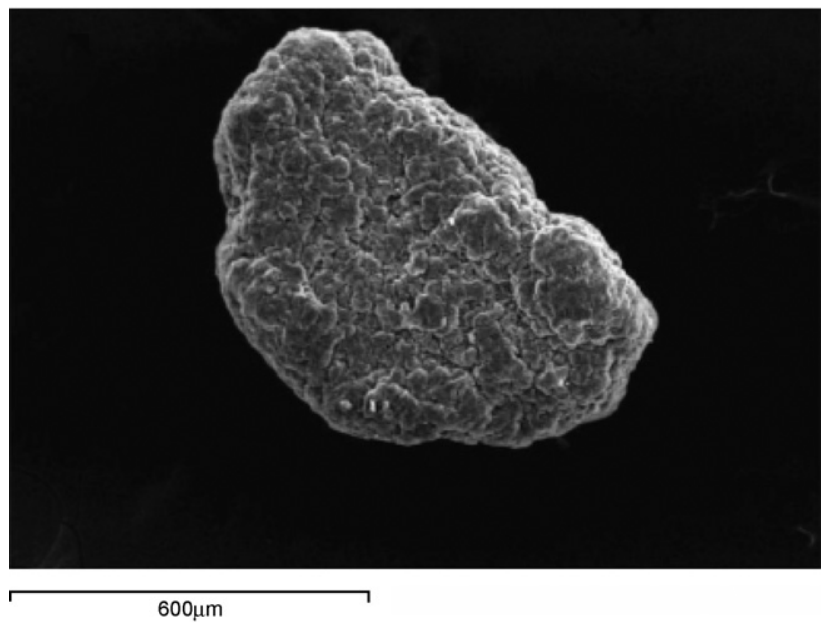

Fig. 1 - Morphology of phenol granules by SEM imaging. 


\section{Results}

\subsection{Characteristics of phenol-degrading granule}

Fig. 1a presents SEM images of cultivated, phenol-fed granules. The granules had a compact surface and an equivalent diameter of approximately $900 \mu \mathrm{m}$. This batch of granules exhibited a phenol degradation rate of near $40 \mathrm{mg}$ phenolgVSS${ }^{-1} \mathrm{~h}^{-1}$ at $1000 \mathrm{mgl}^{-1}$ phenol without a phase lag (Adav et al., 2007a).

The proteins, carbohydrates, and lipids in control granules were $240 \pm 13,61.0 \pm 9.4$, and $51.1 \pm 7.8 \mathrm{mg} \mathrm{g}^{-1} \mathrm{VSS}$, respectively (Table 1). The protein/carbohydrate ratio was approximately 3.9 for phenol-fed granules. This ratio correlated with that obtained by McSwain et al. (2005), who indicated that their granules had a higher protein than polysaccharide content. We measured the quantities of DNA in formamide and sodium hydroxide extraction EPS, and noted that the quantities were all less than $2 \%$ of total DNA in the aerobic granules. Hence, the present work did not induce serious cell lysis in EPS extraction.
Fig. 2 presents the fluorescent staining results, probed at $240 \mu \mathrm{m}$ from the outer surface of the control granule. The fluorescence intensity plot along the line is indicated in Fig. 2 for distributions of lipids (Nile red), proteins (FITC), cells (SYTO 63), $\alpha$-D-glucopyranose polysaccharides (rhodamineCon A conjugate), dead cells (SYTO blue), and $\beta$-D-glucopyranose polysaccharides (calcofluor white). The protein and dead cells were principally distributed at the core, whereas live cells and $\alpha$-polysaccharides were located at the outer rim of the granules. The $\beta$-polysaccharides were distributed in the core and at the outer rim regimes of the phenol-fed granules. Chen et al. (2007a) identified a similar pattern for EPSs and cell distributions in granules.

\subsection{Hydrolyzed granules}

Table 1 presents the extracted EPS content of hydrolyzed granules. Clearly, hydrolysis using specific enzymes generally removed individual EPS compounds. For example, the granules hydrolyzed using proteinase $\mathrm{K}$ exhibited a protein

Table 1 - Constituents in extracted EPS of the original (control) and hydrolyzed phenol-fed granules

\begin{tabular}{|c|c|c|c|}
\hline Samples & Protein (mgg ${ }^{-1}$ VSS) & Carbohydrate (mg g ${ }^{-1}$ VSS) & Lipid (mg g $\left.{ }^{-1} \mathrm{VSS}\right)$ \\
\hline Control & $240 \pm 13$ & $61.0 \pm 9.4$ & $51.1 \pm 7.8$ \\
\hline Hydrolyzed with proteinase $\mathrm{K}$ & $9.0 \pm 2.8$ & $63.5 \pm 11.1$ & $40.0 \pm 9.2$ \\
\hline Hydrolyzed with lipase & $263 \pm 19$ & $58.9 \pm 14.8$ & $7.0 \pm 2.2$ \\
\hline Hydrolyzed with $\alpha$-amylase & $243 \pm 9.1$ & $27.5 \pm 3.2$ & $39 \pm 11$ \\
\hline Hydrolyzed with $\beta$-amylase & $215 \pm 41$ & $24.1 \pm 7.8$ & $41.3 \pm 9.7$ \\
\hline
\end{tabular}

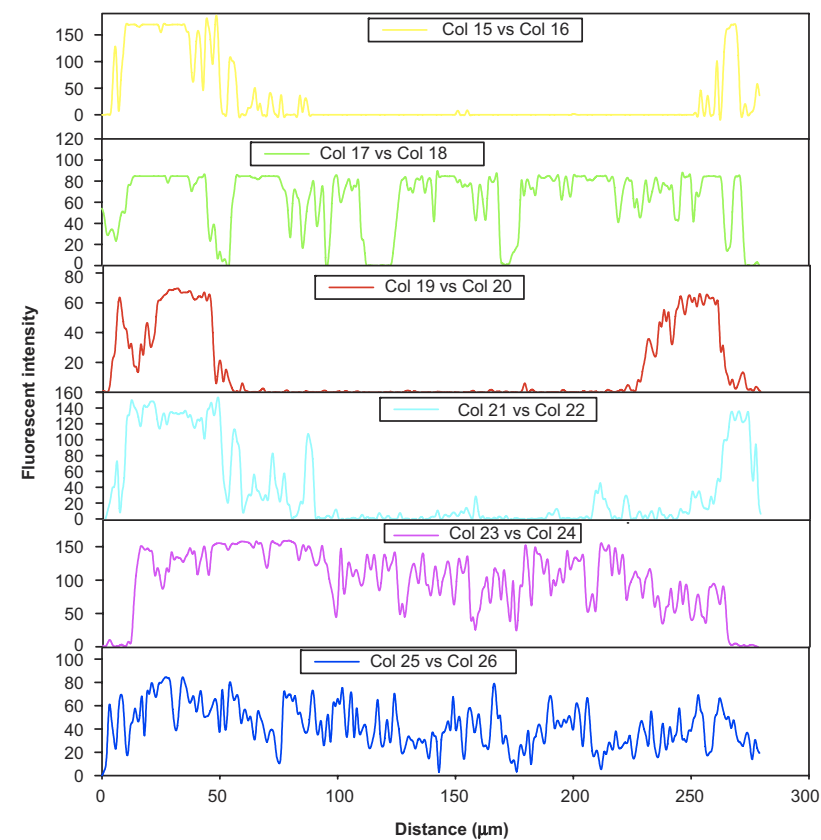

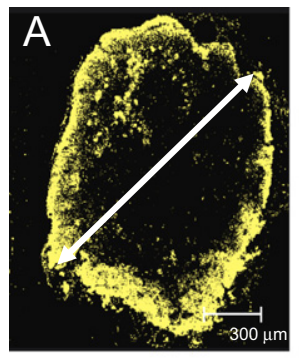
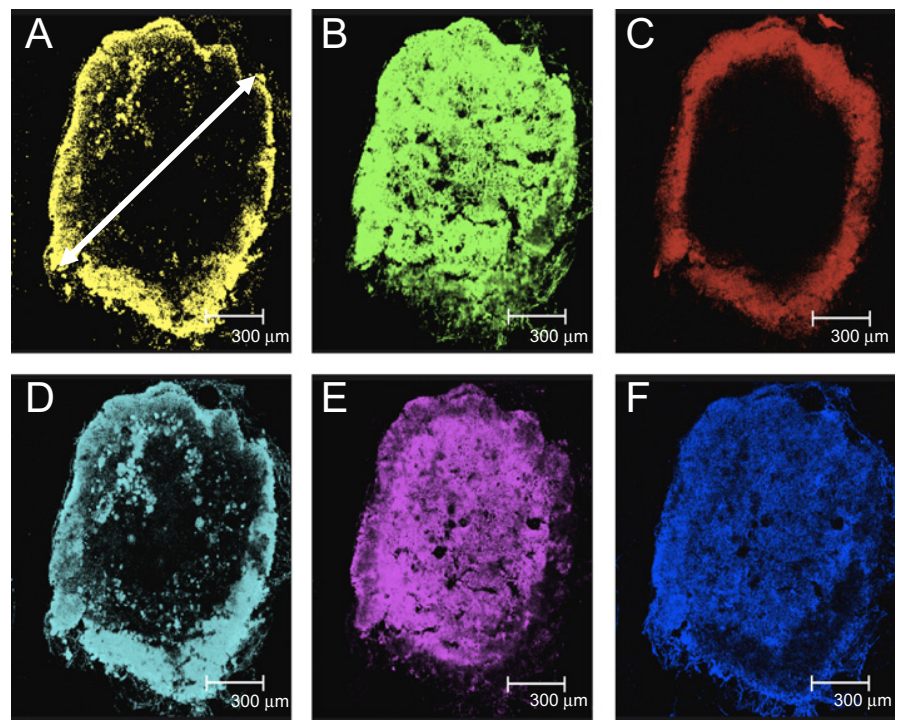

Fig. 2 - CLSM images of phenol-degrading granule (control). (A) Yellow: lipid (Nile red); (B) green: protein (FITC); (C) red: nucleic acid (SYTO 63); (D) light blue: $\alpha$-polysaccharide (Con A); (E) pink: dead cells (SYTO blue); (F) blue: $\beta$-polysaccharide (calcofluor white). 
content that had been reduced from $240 \pm 13$ to $9.0 \pm 2.8 \mathrm{mg} \mathrm{g}^{-1} \mathrm{VSS}$.

Figs. 3-5 present the CLSM images and fluorescence intensity profiles of granules hydrolyzed using proteinase $\mathrm{K}$, lipase, and $\alpha$-amylase, respectively. Taken in conjunction with the data shown in Table 1, it can be seen that each enzyme effectively hydrolyzed specific compounds in the granule interiors. For example, the fluorescence of proteins in proteinase K-hydrolyzed granules was much weaker than in the control counterpart (Fig. 2). However, these granules did not disintegrate following enzymatic hydrolysis.

The $\beta$-polysaccharide-hydrolyzed granules were fragmented into small pieces sized $10-80 \mu \mathrm{m}$. Fig. 6 presents the
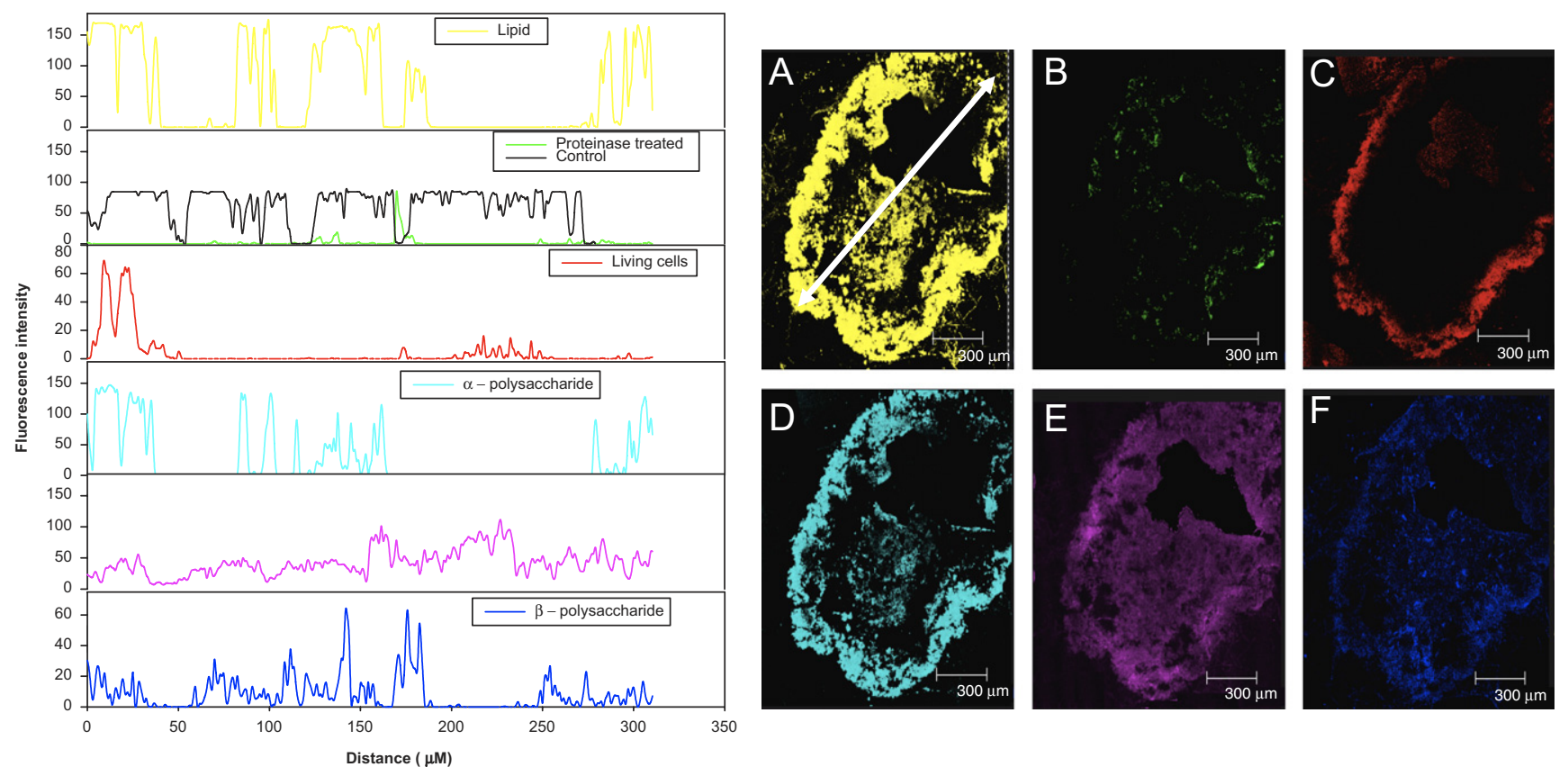

Fig. 3 - CLSM images of proteinase-hydrolyzed granule. (A) Yellow: lipid (Nile red); (B) green: protein (FITC); (C) red: nucleic acid (SYTO 63); (D) light blue: $\alpha$-polysaccharide (Con A); (E) pink: dead cells (SYTO blue); (F) blue: $\beta$-polysaccharide (calcofluor white).
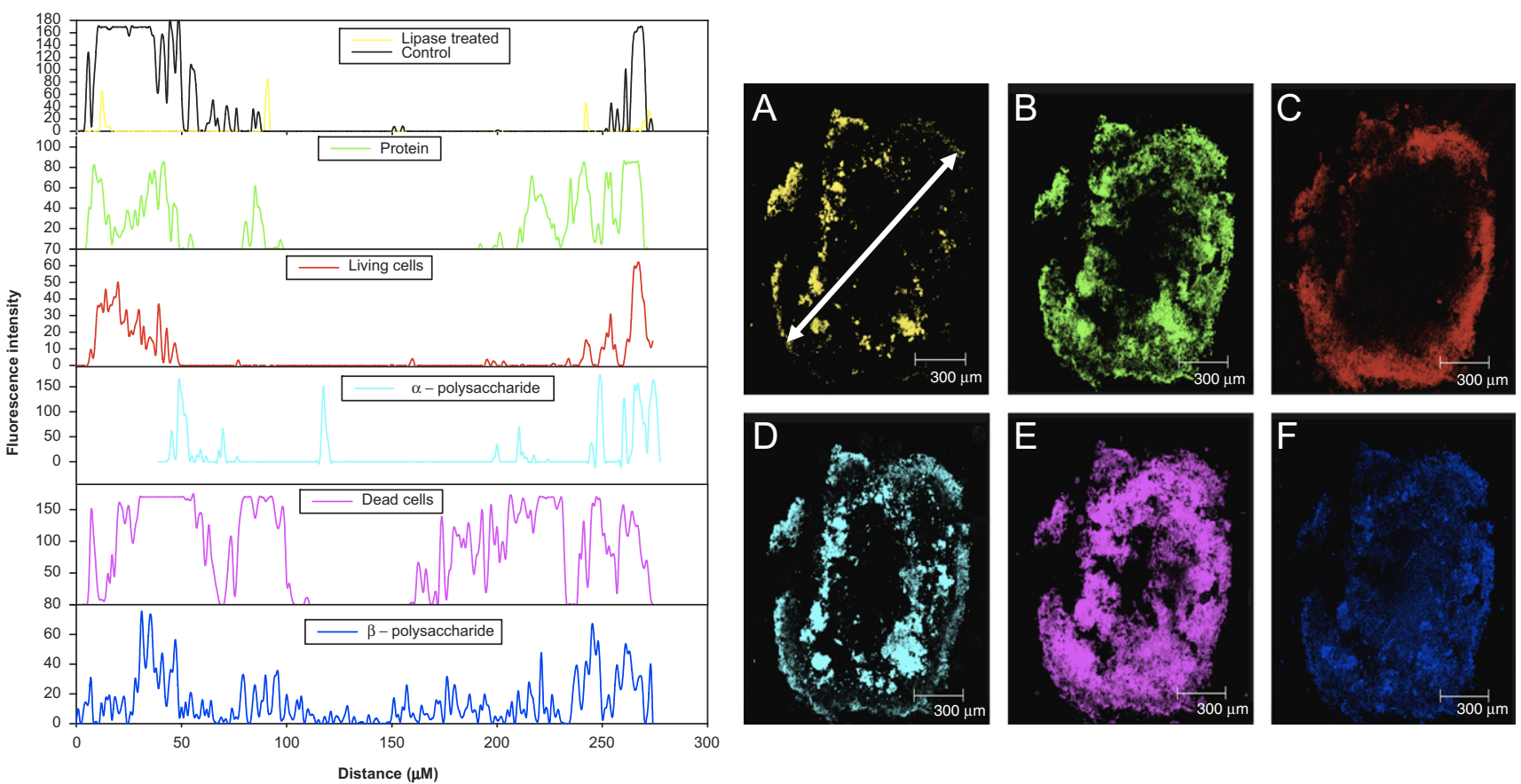

Fig. 4 - CLSM images of lipase-hydrolyzed granule. (A) Yellow: lipid (Nile red); (B) green: protein (FITC); (C) red: nucleic acid (SYTO 63); (D) light blue: $\alpha$-polysaccharide (Con A); (E) pink: dead cells (SYTO blue); (F) blue: $\beta$-polysaccharide (calcofluor white). 
CLSM images of collected fragments and corresponding fluorescence intensity profiles. Staining results indicated that proteins, lipids, and $\alpha$-polysaccharides were distributed over the fragments. Hydrolysis of $\beta$-polysaccharides decreased the structural stability of the granules.

\section{Discussions}

Based on the redundant protein contents measured (Table 1) and the CLSM images (Fig. 2) for the original granules, the
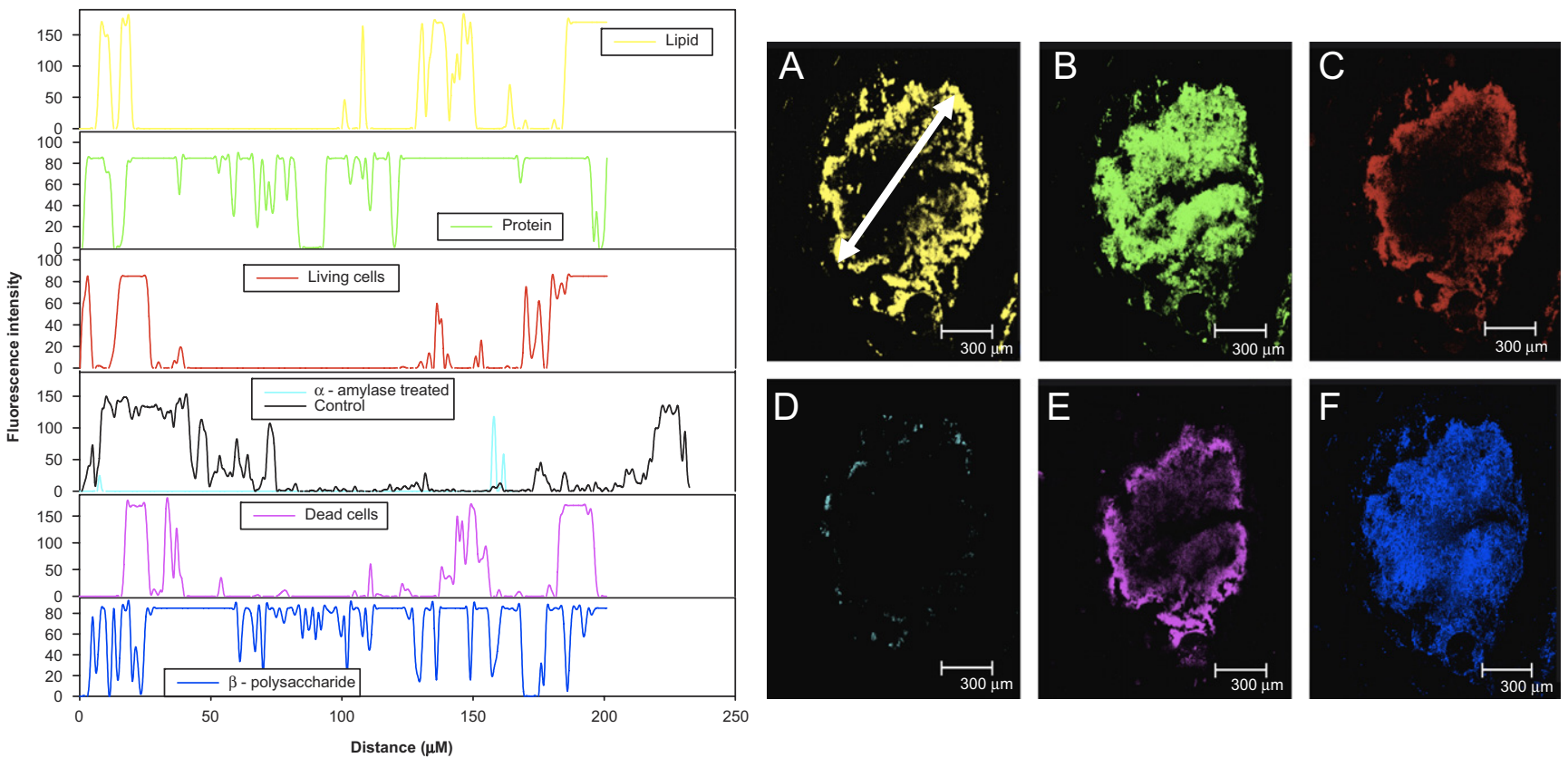

Fig. 5 - CLSM images of $\alpha$-amylase-hydrolyzed granule. (A) Yellow: lipid (Nile red); (B) green: protein (FITC); (C) red: nucleic acid (SYTO 63); (D) light blue: $\alpha$-polysaccharide (Con A); (E) pink: dead cells (SYTO blue); (F) blue: $\beta$-polysaccharide (calcofluor white).
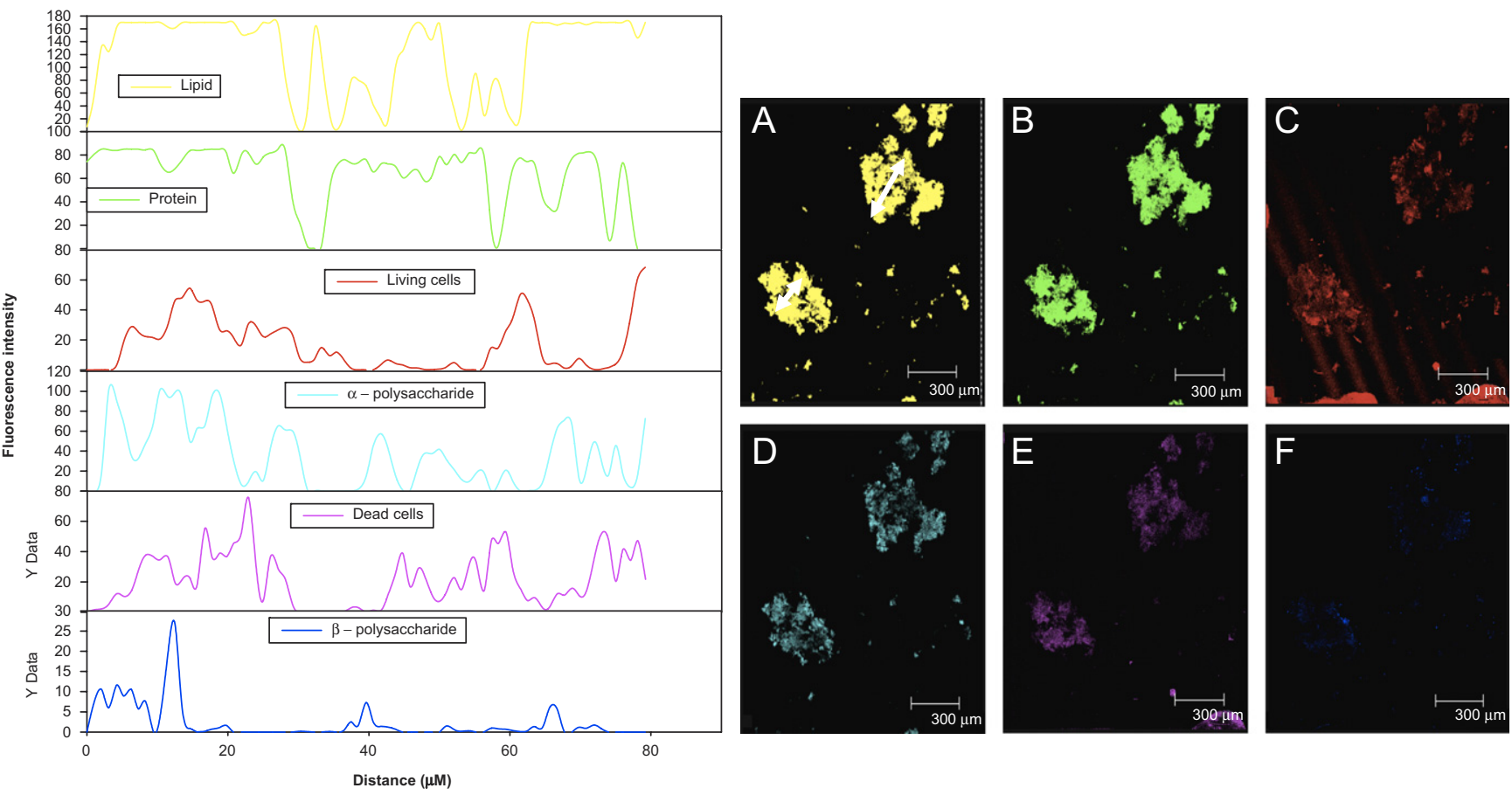

Fig. 6 - CLSM images of $\beta$-amylase-hydrolyzed granule. (A) Yellow: lipid (Nile red); (B) green: protein (FITC); (C) red: nucleic acid (SYTO 63); (D) light blue: $\alpha$-polysaccharide (Con A); (E) pink: dead cells (SYTO blue); (F) blue: $\beta$-polysaccharide (calcofluor white). 
non-cellular protein core may be responsible for granule stability, as suggested by McSwain et al. (2005) and Zhang et al. (2007). However, hydrolysis using proteinase $\mathrm{K}$ emptied the core regime of the granules (Fig. 3), but did not decompose the granules. The non-cellular protein core did not contribute significantly to the structural stability of the present phenolfed granules. Based on results in Table 1 and Figs. 4 and 5, neither lipids nor $\alpha$-polysaccharides corresponded to granule stability. These experimental results support the proposal by Wang et al. (2005) that the $\beta$-polysaccharides are the most important component for granule stability.

The structural paradigm by Wang et al. (2005) assumed that $\beta$-polysaccharide shell formed a continuous and integrated structure that held the soft core of granules. However, in all tested phenol granules, no evidence demonstrated that the $\beta$-polysaccharides formed a continuous shell supporting granule structure (Fig. 2). Conversely, the $\beta$-amylase-hydrolyzed granules contained some large (sized up to $80 \mu \mathrm{m}$ ) and numerous small-sized (about $\leqslant 10 \mu \mathrm{m}$ ) fragments (Fig. 6). Staining results revealed that these large fragments contained concentrated proteins, lipids, and $\alpha$-polysaccharides, compounds resembling those at the outer layers of the original granules (Fig. 2). Hence, these large fragments may originate from the outer layers of granules prior to hydrolysis. The $\beta$-polysaccharides likely form the backbone of a networklike outer layer of embedded proteins, lipids, $\alpha$-polysaccharides, and cells, whose elasticity supports granule mechanical stability. An adequate mechanical strength can be acquired using limited quantities of $\beta$-polysaccharides. This observation shows how granules sustain their structure at a high protein/polysaccharide ratio.

The $\beta$-polysaccharides in the core regime may also contribute to the structural stability of granules. However, the role of $\beta$-polysaccharides in core regime should be less significant than those located on the outer layer. Moreover, cations facilitate cross-linking between ECP (Eriksson and Hardin, 1984; Kielding and Nielsen, 1997), whose role was not discussed herein.

\section{Conclusions}

This study evaluated whether a correlation existed between different EPS constituents and the structural stability of phenol-fed aerobic granules. The contents of proteins, carbohydrates, and lipids in the original granules were $240 \pm 13,61.0 \pm 9.4$, and $51.1 \pm 7.8 \mathrm{mg} \mathrm{g}^{-1} \mathrm{VSS}$, respectively, yielding a protein/carbohydrate ratio of approximately 3.9. A non-cellular core which consisted of proteins and some $\beta$-polysaccharides was found in all tested granules, which may be considered to account for the mechanical strength of granules. However, the selective hydrolysis of lipids, proteins, and $\alpha$ - and $\beta$-polysaccharides using specific enzymes revealed that removing proteins, lipids, and $\alpha$-polysaccharides had minimal impacts on the structural stability of granules. Conversely, hydrolysis of $\beta$-polysaccharides caused granules to disintegrate. The granule structure is viewed as a network with $\beta$-polysaccharides as the backbone for embedded proteins, lipids, $\alpha$-polysaccharides, and cells supported the structural integrity of granules.

\section{R E F E R E N C E S}

Adav, S.S., Chen, M.Y., Lee, D.J., Ren, N.Q., 2007a. Degradation of phenol by aerobic granules and isolated yeast Candida tropicalis. Biotechnol. Bioeng. 96, 844-852.

Adav, S.S., Chen, M.Y., Lee, D.J., Ren, N.Q., 2007b. Degradation of phenol by Acinetobacter strain isolated from aerobic granules. Chemosphere 67, 1566-1572.

APHA, 1998. Standard Methods for the Examination of Water and Wastewater, 20th ed. American Public Health Association, Washington, DC.

Beun, J.J., Hendriks, A., Van Loosdrecht, M.C.M., Morgenroth, E., Wilderer, P.A., Heijnen, J.J., 1999. Aerobic granulation in a sequencing batch reactor. Water Res. 33, 2283-2290.

Cammarota, M.C., Sant'Anna, G.L., 1998. Metabolic blocking of exopolysaccharides synthesis: effects on microbial adhesion and biofilm accumulation. Biotechnol. Lett. 20, 1-4.

Chen, M.Y., Lee, D.J., Tay, J.H., 2007a. Distribution of extracellular polymeric substances in aerobic granules. Appl. Microbiol. Biotechnol. 73, 1463-1469.

Chen, M.Y., Lee, D.J., Tay, J.H., 2007b. Staining of extracellular polymeric substances and cells in bio-aggregates. Appl. Microbiol. Biotechnol. 75, 467-474.

Chiu, Z.C., Chen, M.Y., Lee, D.J., Tay, S.T.L., Tay, J.H., Show, K.Y., 2006. Diffusivity of oxygen of aerobic granules. Biotechnol. Bioeng. 94, 505-513.

Costerton, J.W., Irvin, R.T., Cheng, K.J., 1981. The bacterial glycocalyx in nature and disease. Annu. Rev. Microbiol. 35, 299-324.

de Kreuk, M.K., Pronk, M., van Loosdrecht, M.C.M., 2005. Formation of aerobic granules and conversion processes in an aerobic granular sludge reactor at moderate and low temperatures. Water Res. 39, 4476-4484.

Eriksson, L., Hardin, A.M., 1984. Settling properties of activated sludge related to floc structure. Water Sci. Technol. 16, 55-68.

Frolund, B., Palmgren, R., Keiding, K., Nielsen, P.H., 1996. Extraction of extracellular polymers from activated sludge using a cation exchange resin. Water Res. 30, 1749-1758.

Gaudy, A.F., 1962. Colorimetric determination of protein and carbohydrate. Ind. Water Wastes 7, 17-22.

Hwang, K.J., You, S.F., Don, T.M., 2006. Disruption kinetics of bacterial cells during purification of poly-beta-hydroxyalkanoate using ultrasonication. J. Chin. Inst. Chem. Eng. 37, 209-216.

Jiang, H.L., Tay, J.H., Tay, S.T.L., 2002. Aggregation of immobilized activated sludge cells into aerobically grown microbial granules for the aerobic biodegradation of phenol. Lett. Appl. Microbiol. 35, 439-445.

Jiang, H.L., Tay, J.H., Tay, S.T.L., 2004. Changes in structure, activity and metabolism of aerobic granules as a microbial response to high phenol loading. Appl. Microbiol. Biotechnol. 63, 602-608.

Kielding, K., Nielsen, P., 1997. Desorption of organic macromolecules from activated sludge: effect of ionic composition. Water Res. 31, 1665-1671.

Liu, Y., Tay, J.H., 2004. State of the art of biogranulation technology for wastewater treatment. Biotechnol. Adv. 22, 533-563.

Liu, Y., Liu, Q.S., Qin, L., Tay, J.H., 2004a. Comments on “Effect of extended idle conditions on structure and activity of granular activated sludge" by Zhu and Wilderer. Water Res. 38, 3465-3466.

Liu, Y.Q., Liu, Y., Tay, J.H., 2004b. The effects of extracellular polymeric substances on the formation and stability of biogranules. Appl. Microbiol. Biotechnol. 65, 143-148.

Lowry, O.H., Rosebrough, N., Farr, A.L., Randall, R.J., 1951. Protein measurements using Folin phenol reagent. J. Biol. Chem. 193, 265-275. 
McSwain, B.S., Irvine, R.L., Hausner, M., Wilderer, P.A., 2005. Composition and distribution of extracellular polymeric substances in aerobic flocs and granular sludge. Appl. Environ. Microbiol. 71, 1051-1057.

Morgenroth, E., Sherden, T., Van Loosdrecht, M.C.M., Heijnen, J.J., Wilderer, P.A., 1997. Aerobic granular sludge in a sequencing batch reactor. Water Res. 31, 3191-3194.

Moy, B.Y.P., Tay, J.H., Toh, S.K., Liu, Y., Tay, S.T.L., 2002. High organic loading influences the physical characteristics of aerobic granules. Lett. Appl. Microbiol. 34, 407-412.

Nielsen, P.H., Jahn, A., 1999. Extraction of EPS. In: Wingender, J., Neu, T.R., Flemming, H.C. (Eds.), Microbial Extracellular Polymeric Substances. Spinger, Berlin, pp. 21-47.

Nielsen, P.H., Frolund, B., Keiding, K., 1996. Changes in the composition of extracellular polymeric substances in activated sludge during anaerobic storage. Appl. Microbiol. Biotechnol. 44, 823-830.

Neu, T.R., 1996. Significance of bacterial surface-active compounds in interaction of bacteria with interfaces. Microbiol. Rev. 60, 151-166.

Peng, D.C., Bernet, N., Delgenes, J.P., Moletta, R., 1999. Aerobic granular sludge-a case report. Water Res. 33, 890-893.

Quarmby, J., Forster, C.F., 1995. An examination of the structure of UASB granules. Water Res. 29, 2449-2454.
Takeda, M., Nakano, F., Nagase, T., Iohara, K., Koizumi, J.I., 1998. Isolation and chemical composition of the sheath of Sphaerotilus natans. Biosci. Biotechnol. Biochem. 62, 1138-1143.

Tay, S.T.L., Moy, B.Y.P., Maszenan, A.M., Tay, J.H., 2005. Comparing activated sludge and aerobic granules as microbial inocula for phenol biodegradation. Appl. Microbiol. Biotechnol. 67, 708-713.

Tsuneda, S., Nagano, T., Hoshino, T., Ejiri, Y., Noda, N., Hirata, A., 2003. Characterization of nitrifying granules produced in an aerobic upflow fludized bed reactor. Water Res. 37, 4965-4973.

Wang, Z.W., Liu, Y., Tay, J.H., 2005. Distribution of EPS and cell surface hydrophobicity in aerobic granules. Appl. Microbiol. Biotechnol. 69, 469-473.

Wu, S.T., Huang, C.C., Yu, S.T., Too, J.R., 2006. Effects of nitrogen and phosphorus on poly-beta-hydroxyalkanoate production by Ralstonia eutropha. J. Chin. Inst. Chem. Eng. 37, 501-508.

Yang, S.F., Tay, J.H., Liu, Y., 2004. Inhibition of free ammonia to the formation of aerobic granules. Biochem. Eng. J. 17, $41-48$.

Zhang, L.L., Feng, X.X., Zhu, N.W., Chen, J.M., 2007. Role of extracellular protein in the formation and stability of aerobic granules. Enzyme Microb. Tech. Available online doi:10.1016/ j.enzmictec.2007.05.001. 